\title{
Proposal of New Psychological Aptitude Tests for Train Operation Staff
}

\author{
Takafumi INOUE \\ Masayoshi SHIGEMORI \\ Senior Researcher Laboratory Head, Assistant Senior Researcher, \\ Keiko KIOKA \\ Safety Psychology Laboratory, Human Science Division
}

Hajime AKATSUKA

Assistant Senior Researcher, Safety Psychology Laboratory, Human Science Division
Yumeko MIYACHI

Assistant Senior Researcher, Safety Analysis Laboratory, Human Science Division

Psychological aptitude tests have been carried out on train operation staff in an attempt to improve safety. We searched for a test that would enable us to predict the human errors that are most likely to occur under current working conditions. First, we interviewed railway company experts to identify those errors. Next, we carried out personal computer experiments to simulate occurrences of these errors then applied 20 kinds of tests to 79 subjects. Consequently, we found a correlation between the error occurrence tendencies in the experiments and the actual test results. Based on these results, we have proposed effective tests according to the type of tasks undertaken.

Keywords: train operation aptitude test, human error, risk, attention span, multiplex selective reaction test

\section{Introduction}

Psychological aptitude tests for train operation staff, otherwise known as train operation aptitude tests, have been implemented to check the aptitude required to perform train operation work.

In Japan Railway (JR) companies, four tests are implemented for every train driver, as described in Table $1^{1)}$. Five further tests are performed on Shinkansen train drivers and traffic controllers.

Conductors, dispatchers, and supervisors responsible for the maintenance of track and electrical facilities each take two or three tests.

Table 1 Train operation aptitude test items [Yabuhara, 1988]

\begin{tabular}{ll}
\hline \multicolumn{1}{c}{ Test } & \multicolumn{1}{c}{ Contents } \\
\hline Task performance test & $\begin{array}{l}\text { For measuring characteristics (stability, } \\
\text { rapidness, and accuracy, etc.) of task per- } \\
\text { formance } \\
\text { Intelligence test }\end{array}$ \\
& $\begin{array}{l}\text { For measuring intellectual abilities such } \\
\text { as perception, reasoning, memory, and com- } \\
\text { putation capability }\end{array}$ \\
Attention distribution test & $\begin{array}{l}\text { For measuring abilities to distribute and } \\
\text { maintain attention } \\
\text { Choice reaction test }\end{array}$ \\
& For measuring rapidness and accuracy of \\
& choice reaction to stimulus \\
\hline
\end{tabular}

\section{Reexamination of train operation aptitude test}

The train operation aptitude test system has remained essentially unchanged for approximately 50 years ${ }^{2}$.

In that time, both the number of trains and the speeds at which trains operate have increased, and great advances have been made in automation. Furthermore, safety installation functions have improved and the possibility that an employee would cause an accident thereby lessened. Under such circumstances, the type and level of aptitude demanded of employees have changed.

We took into consideration that the type and level of demands placed on employees' psychological characteristics in order for them to conduct train operations safely had changed. Moreover, as numbers of elderly or female employees increased, it remained to be verified whether the train operation aptitude test could be adapted to them.

Then, we conducted research into the proposal for a new train operation aptitude test system.

\section{Correlation between accidents and train operation aptitude test results}

The correlation between accidents and results from the current train operation aptitude test has been examined several times in the past. Concerning the task performance test, the correlation with accidents has always been detected ${ }^{3)-7 \text { ). }}$.

Table 2 shows the accident index according to task performance test results, based on the previous research. The accident index shows the possibility of an accident occurring in each group. It uses 100 as a base figure for the accident rate of each result group and the overall accident rate. The larger the accident index value, the higher the likelihood of an accident occurring. The target accident is one caused by employee error, including operational accidents, accidents involving injury or loss of life, accidents that caused serious operational disruption, and others.

According to the analysis carried out by Yabuhara in $1985^{5)}$, the test result accident indices were 86, 96 and 114 for high rank, middle rank, and low rank, respectively; in Yabuhara's 1987-1988 analysis ${ }^{6)}$, the same ranks scored 
Table 2 Accident index according to task performance test results

\begin{tabular}{cccccc}
\hline \multirow{2}{*}{ Year } & $\begin{array}{c}\text { Number of persons } \\
\text { involved in accidents }\end{array}$ & $\begin{array}{c}\text { Resultant rank of task performance test } \\
\text { rank }\end{array}$ & $\begin{array}{c}\text { Middle } \\
\text { rank }\end{array}$ & $\begin{array}{c}\text { Low } \\
\text { rank }\end{array}$ & $\begin{array}{c}\text { Other } \\
\text { ranking } \\
\text { categories }\end{array}$ \\
\hline 1985 & 509 & 86 & 96 & 114 & 107 \\
\hline $1987-88$ & 339 & 92 & 95 & 108 & 136 \\
\hline
\end{tabular}

92, 95 and 108, respectively. Both studies showed that a group with lower results has a larger accident index.

\section{Fundamental concept of train operation aptitude test}

Table 3 shows the classification of employee errors.

Human error means phenomena that have brought about unintentional results.

Loss of consciousness caused by illness, taking a nap and a lack of ability caused by limited knowledge or skill all caused errors. These can be detected by medical checks, rectified by offering lifestyle guidance and attitude education, and knowledge or skill examinations, respectively.

Violations are classified from a different point of view. The violations can be roughly divided into two categories: violations due to error or a lack of ability and intentional violations. Sabotage and criminal action are also included under intentional violations.

Thus, the concept of train operation aptitude was defined as detecting "the individual traits that would likely make an individual prone to human error leading to a train collision and derailment" ${ }^{8)}$.

Table 3 Classification of employee errors

\begin{tabular}{lll}
\hline \multicolumn{2}{c}{ Class } & \multicolumn{1}{c}{ Check \& countermeasures } \\
\hline Human error & & Test \\
Loss of & Illness & Medical check \\
consciousness & Nap & Lifestyle guidance \& attitude education \\
Lack of ability & Knowledge & Examination \\
& Skill & Examination \\
\hline Violation & Consequential & \\
& Intentional & Attitude education
\end{tabular}

\section{General method}

We carried out this research using the following procedures. Initially, we created experimental tasks that simulate human error actions likely to cause an accident. As subjects, we selected students and older people who were not involved in train operations. This was intentional, as our aim was to include personnel that would likely be prone to human error. We carried out tests and human error simulation experiments on the same subjects, finally investigating the correlation between them.

Based on the results, we proposed recommended tests.
6. Risk assessment of human error assumptions and error type classification

\subsection{Risk assessment of human error assumptions}

As was intended, we investigated this by hearing from expert railway company personnel experienced in train operations and accidents. We asked them what kinds of human error, train collisions or derailments might occur in the future.

For example, on existing narrow-gauge lines, train derailments due to a human error caused by not checking a departure signal. On the Shinkansen, safety equipment has prevented the occurrence of human errors and derailments of this nature. Table 4 shows the number of the selected human error assumptions.

For the next stage, we performed a risk assessment of human error assumptions. The risk took into consideration "generating frequency (task frequency, error probability, probability of leading to an accident)," and "the extent of damage." Carrying out the paired comparison of two errors in the same task, experts were asked which represented the higher risk. Next, carrying out the paired comparison of two tasks containing some errors, experts were again asked which represented the higher risk. The consultation result in such a layered structure was combined, and the relative risk assessment value computed.

Furthermore, in order to clarify the risk each employee carries, the risk assessment values for a particular condition were divided by the number of employees associated with that condition (Table 5) ${ }^{9}$. Consequently, drivers on narrow-gauge lines had the highest risk assessment value, followed by transportation instruction members on narrow-gauge lines.

Table 4 Number of selected human error assumptions

\begin{tabular}{lcc}
\hline & \multicolumn{2}{c}{ Number of errors } \\
\cline { 2 - 3 } & Narrow-gauge lines & Shinkansen \\
\hline Driver & 116 & 20 \\
\hline Traffic controller & 30 & 4 \\
\hline Conductor & 25 & 16 \\
\hline Dispatcher & 82 & 8 \\
\hline Supervisor & 35 & 2 \\
\hline
\end{tabular}

Table 5 Relative risk assessment values per employee

\begin{tabular}{lcc}
\hline & \multicolumn{2}{c}{ Risk } \\
\cline { 2 - 3 } & Narrow-gauge lines & Shinkansen \\
\hline Driver & .770 & .023 \\
\hline Traffic controller & .157 & .006 \\
\hline Conductor & .007 & .000 \\
\hline Dispatcher & .007 & .000 \\
\hline Supervisor & .034 & .001 \\
\hline
\end{tabular}

\subsection{Cognitive human error mechanism and risk assessment according to human error type}

Types of human error have been classified by a combination of two dimensions induced by a cognitive human 
Table 6 Types of human error assumptions

\begin{tabular}{|c|c|c|c|}
\hline Task & Human error & Explanation & Type \\
\hline Starting signal check & Signal not checked & $\begin{array}{l}\text { Since start signal always indicates moving off, it becomes a } \\
\text { habit to think it permissible to disregard it. Error may occur } \\
\text { when attention distracted by making up for lost time. }\end{array}$ & $\begin{array}{l}\text { Efficiency-first error by dis- } \\
\text { traction of attention }\end{array}$ \\
\hline $\begin{array}{l}\text { Giving stop signal to re- } \\
\text { lief train }\end{array}$ & $\begin{array}{l}\text { Moves without asking traffic con- } \\
\text { trol for permission }\end{array}$ & $\begin{array}{l}\text { In the event of stops and starts between stations, it becomes } \\
\text { habit not to ask traffic control for permission. Error may occur } \\
\text { when attention distracted by wanting to get to a station quickly. }\end{array}$ & $\begin{array}{l}\text { Habitual error by distraction } \\
\text { of attention }\end{array}$ \\
\hline $\begin{array}{l}\text { Emergency stop } \\
\text { procedures }\end{array}$ & Procedures not followed & $\begin{array}{l}\text { Driver forgets because in a state of shock and attention dis- } \\
\text { tracted by other matters. }\end{array}$ & $\begin{array}{l}\text { Prospective memory error by } \\
\text { distraction of attention }\end{array}$ \\
\hline $\begin{array}{l}\text { Emergency brake } \\
\text { operation when } \\
\text { abnormal event occurs }\end{array}$ & $\begin{array}{l}\text { Emergency brake not operated or } \\
\text { operated late }\end{array}$ & $\begin{array}{l}\text { Driver has developed habit of using emergency brake as little } \\
\text { as possible. Error may occur when attention is saturated. }\end{array}$ & $\begin{array}{l}\text { Efficiency-first error by } \\
\text { saturation of attention }\end{array}$ \\
\hline $\begin{array}{l}\text { Stop operation } \\
\text { procedure before going } \\
\text { back into station }\end{array}$ & $\begin{array}{l}\text { Does not stop but goes back into } \\
\text { station without asking traffic con- } \\
\text { trol for permission }\end{array}$ & $\begin{array}{l}\text { Driver has developed habit of not stopping before a station } \\
\text { under normal operation. Error may occur when attention is } \\
\text { saturated after operating at low speed for a lengthy period of } \\
\text { time. }\end{array}$ & $\begin{array}{l}\text { Habitual error by saturation } \\
\text { of attention }\end{array}$ \\
\hline As above & As above & Driver forgets because attention is saturated. & $\begin{array}{l}\text { Prospective memory error by } \\
\text { saturation of attention }\end{array}$ \\
\hline
\end{tabular}

Table 7 Relative risk assessment value classified by human error type

\begin{tabular}{|c|c|c|c|c|c|c|}
\hline & $\begin{array}{l}\text { Habitual error by } \\
\text { distraction of atten- } \\
\text { tion }\end{array}$ & $\begin{array}{l}\text { Habitual error by } \\
\text { saturation of atten- } \\
\text { tion }\end{array}$ & $\begin{array}{l}\text { Efficiency-first er- } \\
\text { ror by distraction of } \\
\text { attention }\end{array}$ & $\begin{array}{l}\text { Efficiency-first er- } \\
\text { ror by saturation of } \\
\text { attention }\end{array}$ & $\begin{array}{l}\text { Prospective memory } \\
\text { error by distraction } \\
\text { of attention }\end{array}$ & $\begin{array}{l}\text { Prospective memory } \\
\text { error by saturation of } \\
\text { attention }\end{array}$ \\
\hline Driver & 0.15 & 0.02 & 0.52 & 0.05 & 0.21 & 0.06 \\
\hline Traffic controller & 0.14 & - & 0.60 & 0.02 & 0.22 & 0.02 \\
\hline Conductor & 0.20 & - & 0.26 & - & 0.54 & - \\
\hline Dispatcher & 0.25 & - & 0.18 & - & 0.57 & - \\
\hline Supervisor & - & - & 0.94 & - & 0.06 & - \\
\hline
\end{tabular}

error mechanism. One dimension is deficiency of attention, which includes distraction and saturation of attention factors, the other is an activation failure of a procedural schema for action and decision, which includes inactivation of a correct procedural schema, an activated habitual incorrect schema, and activated efficient incorrect schema factors. Six human error types were configured incorporating these five factors ${ }^{10}$ ).

Table 6 shows examples of types of human error assumptions. The risk assessment value of each error was totaled for every error type classification using this classification result. Table 7 shows the relative risk assessment value of each error type according to each occupational description and equipment condition.

The type of human error that has the largest risk was a driver's efficiency-first error by distraction of attention.

\section{Validity evaluation of test by error simulation experiment}

\subsection{Participants}

Participants were selected from a participant pool that had already taken the task performance test. Table 8 shows the details of participants.
Table 8 Details of participants

\begin{tabular}{lcccc}
\hline Task performance test & & $\begin{array}{c}\text { Older } \\
\text { male }\end{array}$ & $\begin{array}{c}\text { Young } \\
\text { male }\end{array}$ & $\begin{array}{c}\text { Young } \\
\text { female }\end{array}$ \\
\hline Average test grade & Number & 10 & 16 & 14 \\
& Age range & $55 \sim 69$ & $19 \sim 24$ & $19 \sim 22$ \\
Lower test grade & Number & 10 & 14 & 15 \\
& Age range & $57 \sim 67$ & $19 \sim 23$ & $20 \sim 21$ \\
\hline
\end{tabular}

\subsection{Error simulation experiment}

A laptop computer with a color screen with response keys designed for the experiment controlled the stimulus display and data collection.

An example of a task simulating habitual error by distraction of attention was as follows: At the beginning, participants were asked to listen to and memorize a combination of random digits. Subsequently, a stimulus was presented on the screen. The stimulus for incongruent trials was, for example, "red" printed in blue (interference stimulus). In addition, the stimulus for neutral trials was a non-word, such as "++", printed in red (interference-less stimulus). Participants were required to respond to the color by pressing a key as quickly as possible. Then they were instructed to recite the digits in 
sequence.

Mean time interference was calculated by subtracting the mean response time in the incongruent trials from mean response time in the neutral trials. Mean error interference was calculated by a comparable procedure.

In the experiment assessing prospective memory error, the subject was asked to press a key at preset times. The reaction time logarithm was made into the index.

\subsection{Tests}

We chose a task performance test and a choice reaction test because they were the main tests on the present test system. We also chose a complex coordination test because it related to the correspondence capability at the time of abnormalities.

(1) Task performance test

This test measures task performance characteristics (stability, speed, accuracy, etc.).

(2) Choice reaction test

This test measures the speed and accuracy of choice in reaction to color stimuli.

(3) Complex coordination test

This test measures the distribution power of attention, speed of operation, and composure.

We searched for tests that could predict an accident and an error with higher accuracy when compared with the present tests. We discovered a multiplex reaction test currently carried out in France by SNCF and in the Netherlands by NS. This test was adopted as it had been reported to have a correlation with an actual accident ${ }^{11)}$. Moreover, we adopted a multiplex selective reaction test as a test of the same kind in Japanese.

(4) Vienna Determination Test

This test measures the ability to react quickly and correctly to color and aural stimuli using hands and feet. This is the same test used by NS.
(5) Multiplex selective reaction test

This test measures the ability to react quickly and correctly using the hands, and the ability to cope with abnormalities when subjected to stimuli (colors, figures, and sounds). This test was developed by JR East Japan's Safety Research Laboratory.

Furthermore, we created two new tests and used them on the candidates. These are judged to be useful for the cognitive mechanism of human error.

(6) Attention capacity test

This test forces the subject to memorize a number sequence and measures attention capacity.

(7) Interruption control test

This test measures the ability to control interruption of a habitual act by Stroop task.

\subsection{Correlation with experiment and each test index}

The results of each test made the index the number of correct answers and wrong answers, etc. Tables 9-1 and 9-2 show the correlation coefficient of the error-generating tendency by error imitation experiments, and the results of each test. Correlation was found in all three current tests.

We thought that some tests would have higher validity if they had more human error types correlated and a larger correlation value. Such tests were the complex coordination test, Vienna Determination Test, multiplex selective reaction test, and attention capacity test.

\subsection{Analysis of individual attributes}

We conducted the analysis according to test individual attributes (sex, age). Then, the same correlation was found with every attribute in the tests except in the cases of the choice reaction test and the Vienna Determination Test. The subjects with satisfactory test results but who

Table 9-1 Correlation coefficient of error simulation experiments and tests (1)

\begin{tabular}{|c|c|c|c|c|c|c|}
\hline \multirow[b]{2}{*}{ Test } & \multirow[b]{2}{*}{ Index } & \multicolumn{4}{|c|}{ Time interference } & \multirow{2}{*}{$\begin{array}{c}\begin{array}{c}\text { Reaction time } \\
\text { logarithm }\end{array} \\
\text { Prospective } \\
\text { memory error } \\
\text { by saturation of } \\
\text { attention }\end{array}$} \\
\hline & & $\begin{array}{l}\text { Efficiency-first } \\
\text { error by satura- } \\
\text { tion of atten- } \\
\text { tion }\end{array}$ & $\begin{array}{l}\text { Efficiency-first } \\
\text { error by dis- } \\
\text { traction of at- } \\
\text { tention }\end{array}$ & $\begin{array}{c}\text { Habitual error } \\
\text { by saturation of } \\
\text { attention }\end{array}$ & $\begin{array}{l}\text { Habitual error } \\
\text { by distraction } \\
\text { of attention }\end{array}$ & \\
\hline \multirow[t]{2}{*}{ Task performance test } & Marks & 0.17 & -0.21 & 0.03 & -0.31 & 0.04 \\
\hline & Amount of work & -0.20 & -0.26 & 0.12 & -0.28 & -0.01 \\
\hline \multirow[t]{2}{*}{ Choice reaction test } & Number of correct answers & -0.18 & 0.00 & 0.04 & -0.25 & -0.19 \\
\hline & Number of wrong answers & 0.15 & 0.02 & -0.09 & 0.02 & 0.07 \\
\hline Complex coordination test & Incorrect number & 0.29 & 0.29 & 0.01 & 0.30 & 0.24 \\
\hline Vienna Determination Test & Number of reactions & -0.14 & -0.11 & 0.10 & -0.33 & -0.18 \\
\hline $\begin{array}{l}\text { Multiplex selective reac- } \\
\text { tion test }\end{array}$ & Number of correct answers & -0.21 & -0.19 & -0.10 & -0.23 & -0.31 \\
\hline \multirow[t]{2}{*}{ Attention capacity test } & Number of correct answers (1) & -0.03 & -0.30 & -0.03 & -0.08 & 0.06 \\
\hline & Number of correct answers (2) & -0.10 & -0.03 & 0.09 & -0.11 & -0.09 \\
\hline \multirow[t]{2}{*}{ Interruption control test } & Reply number interference & 0.03 & 0.25 & -0.05 & 0.22 & -0.11 \\
\hline & Wrong answer number interference & -0.19 & -0.01 & -0.13 & -0.10 & -0.03 \\
\hline
\end{tabular}


Table 9-2 Correlation coefficient of error simulation experiments and tests (2)

\begin{tabular}{|c|c|c|c|c|c|c|}
\hline \multirow[b]{2}{*}{ Test } & \multirow[b]{2}{*}{ Index } & \multicolumn{4}{|c|}{ Error interference } & \multirow{2}{*}{$\begin{array}{c}\text { Reaction time } \\
\text { logarithm }\end{array}$} \\
\hline & & $\begin{array}{l}\text { Efficiency-first } \\
\text { error by satura- } \\
\text { tion of atten- } \\
\text { tion }\end{array}$ & $\begin{array}{l}\text { Efficiency-first } \\
\text { error by dis- } \\
\text { traction of at- } \\
\text { tention }\end{array}$ & $\begin{array}{c}\text { Habitual error } \\
\text { by saturation of } \\
\text { attention }\end{array}$ & $\begin{array}{l}\text { Habitual error } \\
\text { by distraction } \\
\text { of attention }\end{array}$ & \\
\hline \multirow[t]{2}{*}{ Task performance test } & Marks & -0.08 & -0.01 & -0.21 & -0.21 & 0.06 \\
\hline & Amount of work & -0.22 & -0.11 & -0.25 & -0.29 & -0.04 \\
\hline \multirow[t]{2}{*}{ Choice reaction test } & Number of correct answers & -0.52 & -0.23 & -0.27 & -0.34 & -0.18 \\
\hline & Number of wrong answers & -0.01 & 0.29 & 0.06 & -0.12 & -0.06 \\
\hline Complex coordination test & Incorrect number & 0.39 & 0.47 & 0.22 & $\mathbf{0 . 3 3}$ & 0.21 \\
\hline Vienna Determination Test & Number of reactions & -0.48 & -0.38 & -0.38 & -0.43 & -0.29 \\
\hline $\begin{array}{l}\text { Multiplex selective reac- } \\
\text { tion test }\end{array}$ & Number of correct answers & -0.52 & -0.35 & -0.35 & -0.34 & -0.19 \\
\hline \multirow[t]{2}{*}{ Attention capacity test } & Number of correct answers (1) & -0.55 & -0.23 & -0.39 & -0.47 & -0.20 \\
\hline & Number of correct answers (2) & -0.31 & -0.12 & -0.29 & -0.34 & -0.27 \\
\hline \multirow[t]{2}{*}{ Interruption control test } & Reply number interference & 0.04 & 0.26 & 0.08 & 0.31 & -0.07 \\
\hline & Wrong answer number interference & -0.16 & -0.15 & 0.20 & 0.00 & 0.05 \\
\hline
\end{tabular}

Bold values: Significant difference in non-correlated test.

$\mathrm{N}=68-79$

showed a high error-generating tendency in the experiments were the young female group in the choice reaction test. The subjects who had gained satisfactory test results but who had a high error-generating tendency in the experiments were the young male group in the Vienna Determination Test. These results ran contrary to the hypothesis.

\section{Evaluation according to task/equipment conditions}

In order to evaluate the validity of the tests according to task/equipment conditions, we created a compre- hensive evaluation value for error-generating tendency. We calculated this value by giving weight to the error simulation experiment results from the risk assessment and an error-type classification result from the human error assumptions. This value is considered to reflect the likelihood of an error being made when each subject works under each condition.

For example, in the case of the track and electrical facility maintenance supervisor on a narrow-gauge line, we multiplied 0.94 and the value from the mean time interference of an efficiency-first error by distraction of attention (Table 4), 0.06 and the mean reaction time logarithm of a prospective memory error by distraction of at-

Table 10-1 Correlation between error-generating tendency according to task/equipment condition and test result using timeinterference and reaction time logarithm

\begin{tabular}{|c|c|c|c|c|c|c|c|c|}
\hline \multirow[b]{3}{*}{ Test } & \multirow[b]{3}{*}{ Index } & \multicolumn{7}{|c|}{ Existing line } \\
\hline & & $\begin{array}{l}\text { Automatic } \\
\text { train stop } \\
\text { (ATS-P } \\
\text { type) }\end{array}$ & $\begin{array}{c}\text { Automatic } \\
\text { train stop } \\
\text { (ATS-S } \\
\text { type) }\end{array}$ & $\begin{array}{c}\text { Single-track } \\
\text { non-PRC }\end{array}$ & $\begin{array}{c}\text { Double-track } \\
\text { PRC }\end{array}$ & & & \\
\hline & & Driver & Driver & $\begin{array}{c}\text { Traffic } \\
\text { controller }\end{array}$ & $\begin{array}{c}\text { Traffic } \\
\text { controller }\end{array}$ & $\begin{array}{l}\text { Supervi- } \\
\text { sor }\end{array}$ & $\begin{array}{c}\text { Dis- } \\
\text { patcher }\end{array}$ & $\begin{array}{c}\text { Conduc- } \\
\text { tor }\end{array}$ \\
\hline \multirow[t]{2}{*}{ Task performance test } & Marks & -0.13 & -0.17 & -0.16 & -0.04 & -0.20 & -0.14 & -0.20 \\
\hline & Amount of work & -0.25 & -0.27 & -0.24 & -0.14 & -0.25 & -0.23 & -0.22 \\
\hline Choice reaction test & Number of correct answers & -0.19 & -0.15 & -0.22 & -0.18 & 0.00 & -0.22 & -0.21 \\
\hline Complex coordination test & Incorrect number & 0.39 & $\mathbf{0 . 3 8}$ & 0.37 & $\mathbf{0 . 3 0}$ & 0.27 & 0.38 & 0.36 \\
\hline Multiplex selective reaction test & Number of correct answers & -0.31 & -0.29 & -0.29 & -0.25 & -0.18 & -0.33 & -0.28 \\
\hline \multirow[t]{2}{*}{ Attention capacity test } & Number of correct answers (1) & -0.26 & -0.27 & -0.27 & -0.26 & -0.26 & -0.23 & -0.28 \\
\hline & Number of correct answers (2) & -0.20 & -0.16 & -0.24 & -0.25 & -0.04 & -0.19 & -0.24 \\
\hline Interruption control test & Reply number interference & 0.14 & 0.18 & 0.14 & 0.04 & 0.23 & 0.14 & 0.12 \\
\hline
\end{tabular}

Bold values: Significant difference in non-correlated test. 
Table 10-2 Correlation between error-generating tendency according to task/equipment condition and test result using errorinterference and reaction time logarithm

\begin{tabular}{|c|c|c|c|c|c|c|c|c|}
\hline \multirow[b]{3}{*}{ Test } & \multirow[b]{3}{*}{ Index } & \multicolumn{7}{|c|}{ Existing line } \\
\hline & & $\begin{array}{l}\text { Automatic } \\
\text { train stop } \\
\text { (ATS-P } \\
\text { type) }\end{array}$ & $\begin{array}{l}\text { Automatic } \\
\text { train stop } \\
\text { (ATS-S } \\
\text { type) }\end{array}$ & $\begin{array}{c}\text { Single-track } \\
\text { non-PRC }\end{array}$ & $\begin{array}{c}\text { Double-track } \\
\text { PRC }\end{array}$ & & & \\
\hline & & Driver & Driver & $\begin{array}{c}\text { Traffic } \\
\text { controller }\end{array}$ & $\begin{array}{c}\text { Traffic } \\
\text { controller }\end{array}$ & $\begin{array}{l}\text { Supervi- } \\
\text { sor }\end{array}$ & $\begin{array}{c}\text { Dis- } \\
\text { patcher }\end{array}$ & $\begin{array}{c}\text { Conduc- } \\
\text { tor }\end{array}$ \\
\hline \multirow[t]{2}{*}{ Choice reaction test } & Number of correct answers & -0.36 & -0.36 & -0.33 & -0.26 & -0.22 & -0.38 & -0.32 \\
\hline & Number of wrong answers & 0.10 & 0.15 & 0.02 & 0.03 & 0.28 & 0.05 & 0.04 \\
\hline Complex coordination test & Incorrect number & 0.49 & 0.51 & 0.43 & 0.36 & 0.43 & 0.46 & 0.43 \\
\hline Multiplex selective reaction test & Number of correct answers & -0.45 & -0.45 & -0.39 & -0.31 & -0.32 & -0.46 & -0.38 \\
\hline Attention capacity test & Number of correct answers (1) & -0.37 & -0.37 & -0.38 & -0.28 & -0.20 & -0.41 & -0.36 \\
\hline Interruption control test & Reply number interference & 0.17 & 0.22 & 0.18 & 0.05 & 0.24 & 0.19 & 0.15 \\
\hline
\end{tabular}

Bold values: Significant difference in non-correlated test.

$\mathrm{N}=73-79$

tention, both were added and considered as the comprehensive evaluation value (time interference).

Tables 10-1 and 10-2 show the correlation coefficient of the comprehensive error-generating tendency evaluation value according to task/equipment conditions and the results of each test. The amount of time interference is used for Table 10-1, and the amount of error number interference is used for Table 10-2.

In the task performance test, with the exception of one equipment condition in a transportation instruction task, correlation was found under all conditions. In the interruption control test, correlation was found only under some conditions. In all other tests, correlation was found under all conditions.

\section{Discussion}

Tests with a large correlation between error-generating tendencies are preferentially recommended. Moreover, when the workload under all task/equipment conditions and all individual attributes are taken into consideration, it is desirable for a common test to be employed.

We are recommending a complex coordination test, a multiplex selective reaction test, and an attention capacity test. Other tests are also feasible within the limits of the corresponding conditions.

By selecting a test that has a higher predictability, safety is maintainable with the smallest number of tests. As for the number of tests performed under each condition, it is rational to make it correspond to the size of the risk according to the condition. Moreover, with regard to test selection, combination is significant so that it may correspond to more human error types. It is desirable to choose tests that take into consideration the degree and quality of operational workload.

We will propose new tests to train operational staff members, analyze the corresponding relationship between the test results and accidents, and verify the validity of the tests.

\section{References}

1) Yabuhara, A., "Psychological aptitude tests adopted in Japanese Railway Industry: In Quest of Safety and Reliability," Japanese Railway Engineering, Vol. 27-4, No. 105, 1988.

2) Kioka K. and Shigemori, M., "Study on Validity of Psychological Aptitude Tests for Train Operation Divisions-A Study on Validity of Intelligence Test Pass or Failure Criterion Adopted in Japanese Railway Industry," Quarterly Report of RTRI, Vol. 43, No. 2, pp. 63-66, 2002.

3) Takeuchi, T., "Railway Accidents and Psychological Aptitude Tests," Railway Labor Science Research, Vol. 29, pp. 127-135, 1975 (in Japanese).

4) Takeuchi, T., "Railway Accidents and Psychological Aptitude Tests (2)," Railway Labor Science Research, Vol. 30, pp. 219-225, 1976 (in Japanese).

5) Yabuhara, A., "Personality and Attitude Trait of Accident Group (1)," Railway Labor Science Research, Vol. 40, pp. 165-178, 1986 (in Japanese).

6) Yabuhara, A., "Relation between Operational Aptitude Test Score and Accidents in Railway," RTRI Report, Vol. 4, No. 3, pp. 9-17, 1990 (in Japanese).

7) Kobori, Y., "Research on Validity of Operational Aptitude Test," RTRI Report, Vol. 5, No. 3, 1991 (in Japanese).

8) Inoue, T., Kioka, K., Akatsuka, H., Miyachi, Y., "Basic Concept of New Psychological Aptitude Tests for Train Operation Divisions," RTRI Report, Vol. 17, No. 1, 2003 (in Japanese).

9) Inoue, T., "Risk Assessment of Human Errors," Railway Research Review, Vol. 61, No. 11, pp. 22-25, 2004 (in Japanese).

10) Shigemori, M., Inoue, T., Sawa, M., "Tasks for Estimating Human Error Tendency," Quarterly Report of RTRI, Vol. 47, No. 4, 2006.

11) van der Fiier, H., and Schoonman, W., "Railway signals passed at danger-Situational and personal factors underlying stop signal abuse," Applied Ergonomics, Vol. 19, No. 2, pp. 135-141, 1988. 